\title{
A NEW AUSTRALIAN SPECIES OF OLEARIA (COMPOSITAE)
}

\author{
N.S, LANDER \\ (Received July 1974)
}

\section{ABSTRACT}

Lander, N.S. (National Herbarium of New South Wales, Sydney, Australia) 1975. A New Australian Species of Olearia (Compositae). Telopea 1 (i): 84-86.-Olearia cordata is described. This species is known only from two small populations on the Central Coast of New South Wales. It is most closely related to O. tenuifolia (DC.) Benth.

\section{Olearia cordata $N$. Lander, sp. nov.}

O. tenuifoliae (DC.) Benth. affinis praecipue differt foliis basi late cordatis vice angustatis et pappo sine serie exteriore pilorum brevium.

Holotype: New South Wales: $\frac{1}{2}$ mile $[0.8 \mathrm{~km}]$ above Wisemans Ferry on road to Maroota, P. Matthew NSW 128087, 2.iii.1973 (NSW). IsOTYPES to be distributed to CANB and $K$.

Ascending branched shrub to $2 \mathrm{~m}$, strongly aromatic. Stems, peduncles and both surfaces of leaves densely covered with both simple hairs and glandular, multicellular, patent hairs together with multicellular, appressed hairs; dorsal surfaces of outer involucral bracts densely covered with glandular, multicellular, patent hairs only. Leaves alternate, sessile, linear, each with broad cordate base and prominent mid-vein, $2.5-4.0 \mathrm{~cm}$ long, $0.4-0.8 \mathrm{~cm}$ wide at the base, margins entire, revolute. Capitula solitary on stout peduncles, each $2.2-3.5 \mathrm{~cm}$ in total diameter; disc $0.3-0.5 \mathrm{~cm}$ in diameter. Involucral bracts in 3-4 rows, lanceolate, acuminate, becoming less hairy towards the disc, inner ones with fimbriate margins, $2.5-5.0 \mathrm{~mm}$ long, c. $0.5 \mathrm{~mm}$ wide. Ray florets $12-18$ in each capitulum, in one row, pistillate; ligules deep blue, $12 \mathrm{~mm}$ long and $1.5 \mathrm{~mm}$ wide, corolla tubes $2.5 \mathrm{~mm}$ long; mature styles c. $5 \mathrm{~mm}$ long, bilobed, each lobe $1 \mathrm{~mm}$ long, $0.1 \mathrm{~mm}$ wide. Pappus of 35-40 minutely barbate hairs, each hair $1.0-3.5 \mathrm{~mm}$ long. Cypsela somewhat flattened, $2.5 \mathrm{~mm}$ long, $0.5 \mathrm{~mm}$ wide, with three prominent ridges on each side, densely clothed with simple hairs. Flowering period: of the specimens examined those collected in November, March and April were flowering.

Distribution: New SOUTH Wales: Central Coast: Known only from two small populations, one on a rocky ridge $\frac{1}{3}$ mile $[0.8 \mathrm{~km}] \mathrm{S}$. of Wiseman's Ferry, Boorman NSW 128085, 4.1908, Evans \& Blaxell NSW 128086, 8.1961, P. Matthew NSW 128087, 3.1973; the other near Fernances Trig., St Albans Common, P. Matthew NSW 122291, 11.1973.

O. cordata appears to be closely related to O. tenuifolia (DC.) Benth. The latter species, which is similar in size and habit to O. cordata, is common in a wide variety of habitats on the Southern Tablelands and Central Western Slopes, and considerably less common on the South Coast, Central Tablelands and Western Plains of New South Wales. $O$. cordata and $O$. tenuifolia are easily distinguished as follows:- 


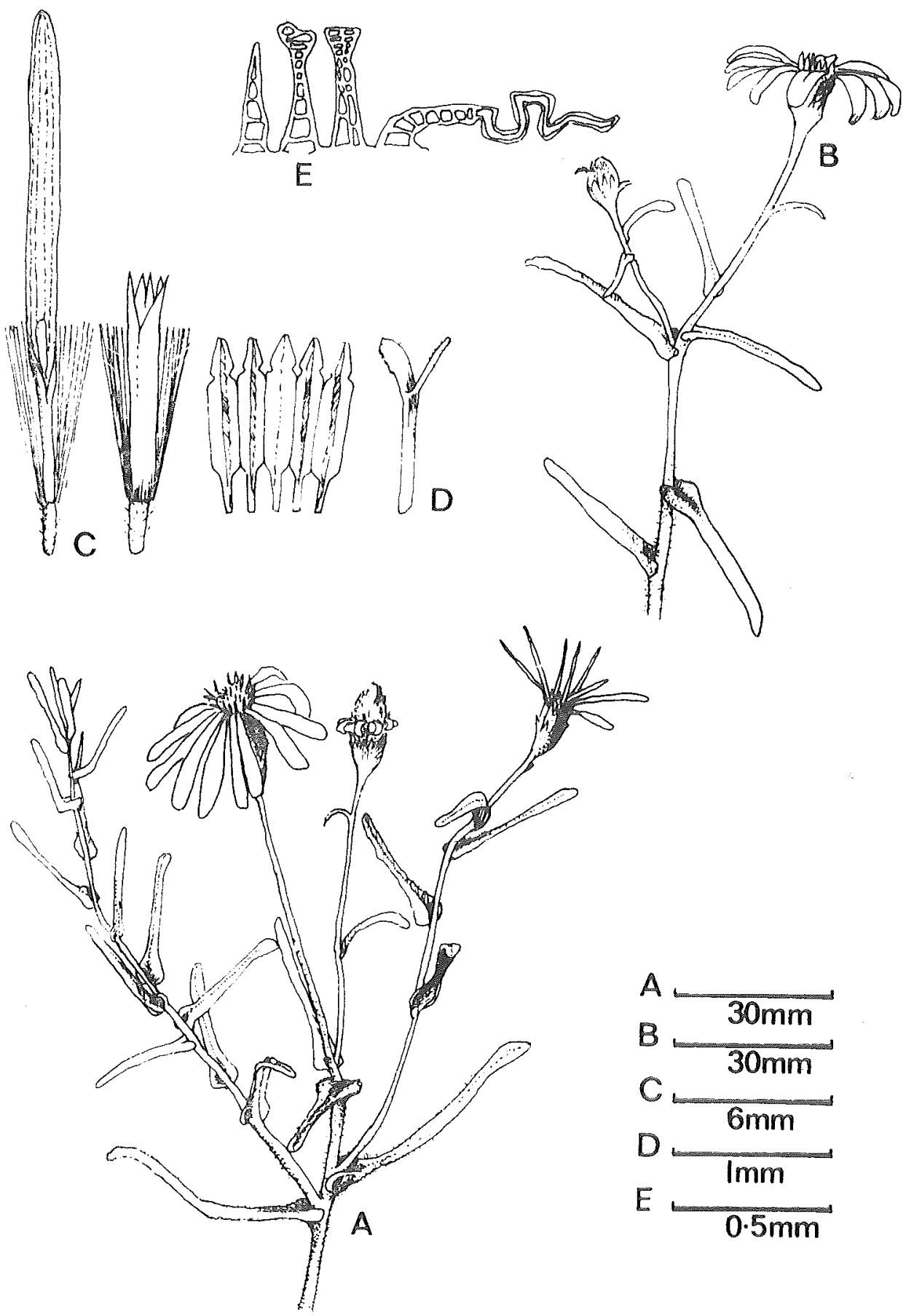

Fig. 1. Olearia cordata. A-B. Flowering branches. C. ray and disc florets. D. anthers and style. E. simple and glandular patent hairs and multicellular appressed hair. 
1. Leaves not crowded, each with a broad, cordate base, densely glandular-hairy, never glabrous. Pappus without an outer row of short bristles. Fruit prominently ribbed

o. cordata

1." Leaves crowded, with narrow bases, glandular-hairy or glabrous, never densely clothed as $O$. cordata. Pappus with an outer row of short bristles. Fruit not prominently ribbed

O. tenuifolia

\section{ACKNOWLEDGEMENTS}

I would like to thank Mr P. Matthew of Wisemans Ferry for drawing my attention to this species and for providing specimens of it. I am most grateful to Mrs Helen Bryant for the illustration. 